\title{
Root Distribution and Tiller Densities of Creeping Bentgrass Cultivars and Greens-type Annual Bluegrass Cultivars in a Putting Green
}

\author{
Eric M. Lyons ${ }^{1}$ \\ Department of Plant Agriculture, Bovey Building, University of Guelph, \\ Guelph, Ontario, N1G 2W1, Canada
}

\author{
Peter J. Landschoot and David R. Huff \\ Department of Crop and Soil Sciences, The Pennsylvania State University, \\ University Park, PA 16802
}

Additional index words. turfgrass species competition, nitrogen fertility, specific root length

Abstract. Little knowledge exists regarding root distribution of creeping bentgrass (Agrostis stolonifera) and annual bluegrass (Poa annua) in root zones of golf course putting greens. To compare root distribution between these species, three experimental cultivars of greens-type annual bluegrass and two commercial cultivars of creeping bentgrass ('Penncross' and 'Penn A-4') were established on an experimental golf green and managed under two nitrogen ( $N$ ) fertility levels (195 and $65 \mathrm{~kg} \mathrm{~N} / \mathrm{ha} /$ year) over a 2year period. Creeping bentgrass had two and three times the total root mass compared with annual bluegrass during the first and second years of the experiment, respectively. At soil depths of 3-12 cm and below $12 \mathrm{~cm}$, creeping bentgrass had three to four times the root mass compared with annual bluegrass at various times during the experiment. During the first year of the experiment, both species exhibited greater than $50 \%$ decrease in total root mass from June to August. During the second year, creeping bentgrass total root mass decreased $10 \%$ to $15 \%$ and annual bluegrass total root mass decreased $25 \%$ to $30 \%$ over the same period. Of the two bentgrasses, 'Penn A-4' creeping bentgrass exhibited greater total root mass only in the second year; however, 'Penn A-4' exhibited greater root mass than 'Penncross' below $12 \mathrm{~cm}$ in both years. Creeping bentgrass cultivars showed greater root mass below $12 \mathrm{~cm}$ at $65 \mathrm{~kg} \mathrm{~N} / \mathrm{ha} /$ year compared with $195 \mathrm{~kg}$ N/ha/year on some sampling dates in both years. Annual bluegrass cultivars showed no change in any root mass parameters in response to $\mathrm{N}$ rates (data not shown), but specific root length (SRL) of annual bluegrass increased under the $65 \mathrm{~kg} \mathrm{~N} / \mathrm{ha} / \mathrm{year}$ rate compared with the $195 \mathrm{~kg}$ N/ha/year rate, whereas SRL of creeping bentgrass was similar at both $N$ rates. Tiller densities of both species increased under the $195 \mathrm{~kg} \mathrm{~N} / \mathrm{ha} /$ year rate. 'Penn A-4' exhibited higher tiller densities than 'Penncross' throughout the experiment and at times was equivalent to the tiller densities of the annual bluegrass cultivars. These results suggest that although creeping bentgrass increases root mass deeper in a putting green root zone mix at lower $N$ rates $(65 \mathrm{~kg} \mathrm{~N} / \mathrm{ha} / \mathrm{year})$, annual bluegrass exhibits plasticity in specific root length in response to different $\mathrm{N}$ rates.

Creeping bentgrass (Agrostis stolonifera L.) and annual bluegrass (Poa annua L.) are the predominant species of grass found on golf course putting greens in the northern United States. The recent selection of high-quality inbred lines of perennial greens-type annual bluegrass has provided opportunities for comparing the competitive vigor of annual bluegrass with creeping bentgrass on putting greens (Huff, 2003, 2004). Understanding growth habits will lead to selection of improved and more competitive cultivars of both species.

Annual bluegrass has been described as having a shallow root system, but this is likely because it is often found on sites with com-

Received for publication 1 June 2011. Accepted for publication 9 Aug. 2011.

${ }^{1}$ To whom reprint requests should be addressed; e-mail elyons@uoguelph.ca. pacted soils (Beard, 1973; Beard et al., 1978; Sprague and Burton, 1937; Youngner, 1959). In non-compacted soils, the root mass of annual bluegrass was comparable to root masses of colonial bentgrass and kentucky bluegrass in the top $7.5 \mathrm{~cm}$ or $12.5 \mathrm{~cm}$ of soil (Sprague and Burton, 1937). When grown in sandy loam soils at increasing bulk densities, no differences in root biomass were detected among annual bluegrass, kentucky bluegrass, and creeping bentgrass plants (Wilkinson and Duff, 1972).

The effects of temperature and other seasonal changes on the rooting of creeping bentgrass on golf greens are becoming better understood (Huang and Gao, 2000), whereas the role of fertility, particularly $\mathrm{N}$ fertility, has been more difficult to ascertain. Some studies have shown less root growth in bentgrass species in response to higher $\mathrm{N}$ rates compared with a lower $\mathrm{N}$ rate (Christians et al., 1979; Madison, 1962; Schlossberg and Karnok,
2001; Schmidt and Blazer, 1967). Other studies have shown increased root growth in bentgrass species in response to higher $\mathrm{N}$ rates compared with a lower $\mathrm{N}$ rate (Bell and Defrance, 1944; Kohlmeier and Eggens, 1983). Kohlmeier and Eggens (1983) found an increase in root growth at higher $\mathrm{N}$ rates in a study focusing on recovery from wear. Schlossberg and Karnok (2001) showed that it is important to determine the distribution of root length density with soil depth in addition to measuring total root length density to assess differences in rooting between cultivars and nutrient regimes.

Annual bluegrass growth and competitiveness is also affected by $\mathrm{N}$ rates (Kohlmeier and Eggens, 1983). Dest and Guillard (1987) showed that withholding $\mathrm{N}$ fertilization from a golf course fairway for up to 3 years reduced the amount of annual bluegrass encroachment into the stand. Although $\mathrm{N}$ additions have been implicated in annual bluegrass encroachment into creeping bentgrass stands, the specific effects of different $\mathrm{N}$ rates on annual bluegrass root growth and competitiveness is not well documented.

Understanding the distribution of root systems and tiller densities of creeping bentgrass and annual bluegrass under different $\mathrm{N}$ levels in sand root zones will aid in our understanding of how these species interact on golf course putting greens. The purpose of our study was to compare root distribution and tiller densities of creeping bentgrass cultivars Penncross (a medium-density, prostrate-growing cultivar released in 1954) and 'Penn A-4' (a highdensity, upright-growing cultivar released in the 1995) to three experimental cultivars of greens-type annual bluegrass throughout two growing seasons at two different $\mathrm{N}$ rates.

\section{Materials and Methods}

Plant materials and growing conditions. Two creeping bentgrass cultivars (Penncross, Penn A-4) and three experimental cultivars of greens-type annual bluegrass ('PSU-97-1', 'PSU-97-2', 'PSU-97-3') were seeded in monocultures into $2.75 \times 4$-m plots on an experimental putting green at a rate of $36.5 \mathrm{~kg} \cdot \mathrm{ha}^{-1}$ during late Sept. 1999. The cultivars were arranged in a randomized strip-split-plot design with three replicates. The root zone consisted of $30.5 \mathrm{~cm}$ of an $85 \%$ sand and $15 \%$ sphagnum peat mixture (v:v) laid over $10 \mathrm{~cm}$ of pea gravel conforming to the USGA specifications (Green Section Staff, 1993). The seedbed was watered to maintain a moist surface for 6 weeks after germination. Mowing height was gradually lowered and an aggressive topdressing program was implemented until a mowing height of $3.2 \mathrm{~mm}$ was reached in late July of the grow-in year (2000). In the grow-in year, all plots were fertilized identically using granular starter fertilizer $(19 \mathrm{~N}-$ 25P-5K) (Scotts Co., Marysville, $\mathrm{OH}$ ) followed by a liquid fertilizer containing $\mathrm{N}$, phosphorus $(\mathrm{P})$, and potassium $(\mathrm{K})$ and a micronutrient solution to allow for optimal grow-in and establishment of the turf, resulting in $175 \mathrm{~kg}$ $\mathrm{N} / \mathrm{ha}, 33 \mathrm{~kg} \mathrm{P} / \mathrm{ha}$, and $104 \mathrm{~kg} \mathrm{~K} / \mathrm{ha}$ during the grow-in season. The experiment began in Spring 
Table 1. Tiller densities and root mass of creeping bentgrass cultivars ('Penn A-4' and 'Penncross') and annual bluegrass cultivars ('PSU-97-1', 'PSU-97-2', 'PSU-97-3') pooled over two different $\mathrm{N}$ rates (65 kg N/ha/year and $195 \mathrm{~kg} \mathrm{~N} / \mathrm{ha} /$ year).

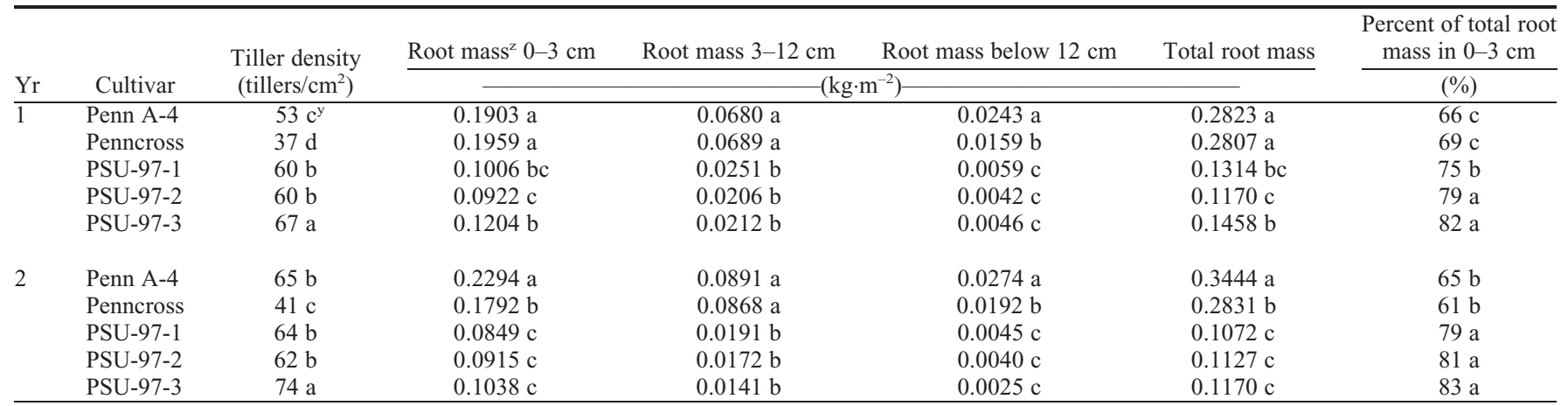

${ }^{\mathrm{z}}$ Root mass data represents ash-free root mass from a 3.5 -cm diameter core.

${ }^{y}$ Means of three replications and nine sample dates (Year 1) or eight sample dates (Year 2) taken from 3.5-cm diameter cores from an experimental putting green. Values with the same letters are not significantly different at the $P<0.05$ level within each year.

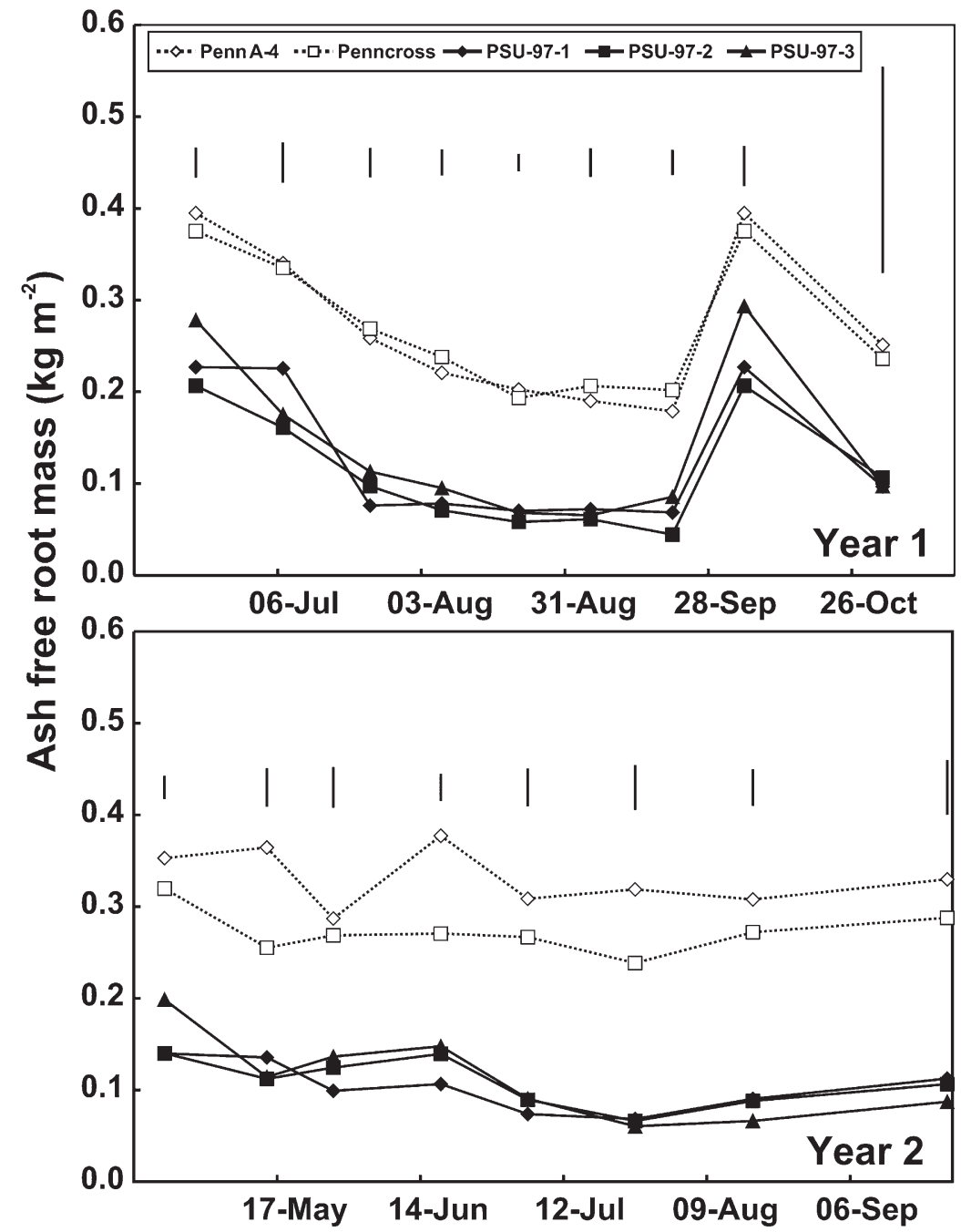

Fig. 1. Total root mass (ash free) per meter squared of surface area of ground of two cultivars of creeping bentgrass ('Penn A-4' and 'Penncross') and three cultivars of annual bluegrass ('PSU-97-1', 'PSU-972', 'PSU-97-3') over 2 years. Bars above each day represent SE values for cultivar difference on each day when day $\times$ cultivar was significant.

2001. In 2001 (Year 1) and 2002 (Year 2), two different $\mathrm{N}$ rates were stripped across the plots. In both years of the experiment, the plots received applications of liquid ammonium nitrate every 10 to $20 \mathrm{~d}$ beginning in May at a rate of $6.1 \mathrm{~kg} \mathrm{~N} / \mathrm{ha}$ and $18.3 \mathrm{~kg} \mathrm{~N} / \mathrm{ha}$ for the low and high $\mathrm{N}$ treatments, respectively. This resulted in $\approx 65 \mathrm{~kg} \mathrm{~N} / \mathrm{ha} /$ year or $195 \mathrm{~kg} \mathrm{~N} / \mathrm{ha} /$ year. Phosphorus and $\mathrm{K}$ were supplemented with applications of calcium phosphate and potassium chloride solution in the spring and fall resulting in $11 \mathrm{~kg} \mathrm{P} / \mathrm{ha}$ and $60 \mathrm{~kg} \mathrm{~K} / \mathrm{ha}$.
Measurements. Tiller density and root mass were measured at three different depths on nine dates from mid-June to early November in Year 1 and on eight dates from late March to late September in Year 2. Four $3.5-\mathrm{cm}$ diameter cores were taken to a depth of $25 \mathrm{~cm}$ from each plot (two from each $\mathrm{N}$ treatment) using a sharpened polyvinyl chloride (PVC) pipe every 10 to $20 \mathrm{~d}$ throughout each growing season. The cores were frozen within the PVC pipe at $-20^{\circ} \mathrm{C}$ before data collection. For each core, the top $3 \mathrm{~mm}$ was removed using a saw for tiller density measurements and to eliminate any stem material from the root samples. The remaining core was then separated into three sections: $0-3 \mathrm{~cm}$, $3-12 \mathrm{~cm}$, and below $12 \mathrm{~cm}$. The roots from each section were washed from the soil by hand with a $1-\mathrm{mm}$ soil sieve under running water held at room temperature.

Fresh weights were recorded and subsamples of the roots were weighed and placed in $15 \%$ ethanol solution for root length analysis. The remaining roots were dried for 24 to $48 \mathrm{~h}$ at $70{ }^{\circ} \mathrm{C}$. Root dry weights were recorded and then samples were ashed in a muffle furnace at $605^{\circ} \mathrm{C}$ until all organic matter was completely combusted, typically $6 \mathrm{~h}$. Ashed samples were weighed and the weight of the ash and any remaining sand in the sample were subtracted from the root dry weight. Root dry weight was then corrected for the fresh weight subsampling.

Root length was determined by staining the ethanol-preserved roots with $0.1 \mathrm{~g} \cdot \mathrm{L}^{-1}$ neutral red dye (Sigma Chemical Co., St. Louis, $\mathrm{MO})$ for $24 \mathrm{~h}$ and scanning them on a flatbed scanner using WinRhizo software (Regent Industries, Canada). Specific root length was determined after calculating the dry weight of the scanned sample using the fresh weight to ashfree dry weight ratio of the whole sample. The calculated dry weight of the scanned sample was then divided by the root length of the scanned sample resulting in the specific root length.

Tiller densities were obtained by separating the top $3 \mathrm{~mm}$ of the core samples into four equal parts and counting the total number of tillers in one-fourth of each core. All root and tiller measurements were averaged to obtain a plot value on each date data were collected. 


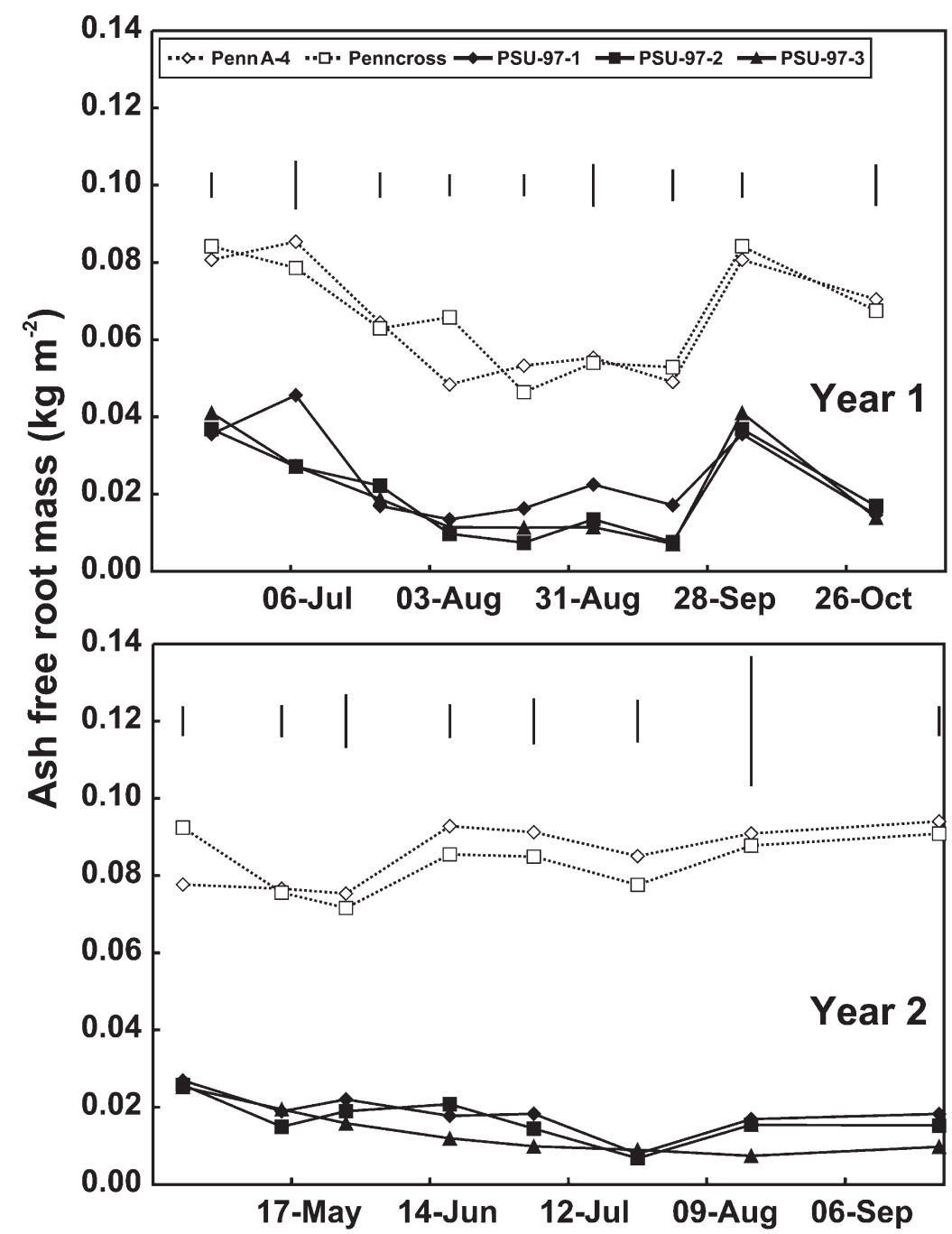

Fig. 2. Root mass (ash free) in the 3- to 12-cm fraction per meter squared of surface area of two cultivars of creeping bentgrass ('Penn A-4' and 'Penncross') and three cultivars of annual bluegrass ('PSU-97-1', 'PSU-97-2', 'PSU-97-3') over 2 years. Bars above each day represent sE values for cultivar difference on each day when day $\times$ cultivar was significant

Cultivar differences were measured by pooling $\mathrm{N}$ treatments. Analyses of variance were performed as repeated measures using the PROC MIXED procedure of the Statistical Analysis System (SAS Inc., Cary, NC). Where appropriate, differences between cultivar means at a given date of harvest or between harvest times for a given cultivar were separated by Fisher's least significance difference test at the 0.05 level. To better understand the effects of the $\mathrm{N}$ treatment within a species, the bentgrass and annual bluegrass data were analyzed separately. In the repeated-measures design, the data from 2001 and 2002 were treated separately (Litell et al., 1996).

\section{Results}

Temperature patterns were similar in both years with the highest temperatures occurring during late July through late August (data not shown), and all plots sustained sufficient monocultures for sampling throughout the duration of the experimental period.

The bentgrass cultivars did not differ from each other in total root mass in Year 1. Of the annual bluegrass cultivars, 'PSU-97-3' and 'PSU-97-1' had greater total root mass than 'PSU-97-2', but they were both less than either of the two bentgrasses (Table 1). In Year 2, 'Penn A-4' had $\approx 25 \%$ more total root mass than 'Penncross', and both creeping bentgrass cultivars had more than twice the total root mass of any of the three annual bluegrass cultivars (Table 1). Annual bluegrass cultivars did not differ from one another in total root mass in Year 2. In Year 1, total root mass for all grasses was greatest on 20 June and 5 Oct. (Fig. 1). Approximately a 50\% reduction in total root mass was observed throughout most of the summer compared with spring, and a second reduction was observed after the first decrease in total root mass was observed throughout the summer of Year 2 from 18 June until 18 Aug. for all cultivars pooled, and a subsequent recovery was not observed in Year 2 (Fig. 1).

Root mass in the 0 - to $3-\mathrm{cm}$ depth followed a similar trend as the seasonal changes in total root mass. Among the annual bluegrasses, 'PSU-97-3' and 'PSU-97-1' had more freeze in Year 1 (Fig. 1). Approximately a 20\% root mass in the 0 - to $3-\mathrm{cm}$ depth in Year 1 than 'PSU-97-2' (Table 1). In Year 2, all three annual bluegrass cultivars had less root mass in the 0 - to $3-\mathrm{cm}$ depth than the creeping bentgrass cultivars with 'Penn A-4' exhibiting greater root mass than 'Penncross' (Table 1). The annual bluegrass selections had a higher percentage of their total root mass in the 0 - to 3-cm depth compared with the two creeping bentgrass cultivars. In Year 1, 'PSU-97-1' had a lower percentage $(75 \%)$ of total root mass in the 0- to 3-cm depth than 'PSU-97-2' $(79 \%)$ and 'PSU-97-3' (82\%). The majority of total root mass for all grasses was found in the 0 - to $3-\mathrm{cm}$ depth throughout the experiment, because $75 \%$ to $85 \%$ and $60 \%$ to $70 \%$ of the total root mass was found in the 0 - to 3-cm depth for the annual bluegrass cultivars and the creeping bentgrass cultivars, respectively (Table 1).

In both years of the experiment, bentgrass cultivars had significantly more root mass in the 3- to $12-\mathrm{cm}$ depth than the annual bluegrass cultivars with approximately three times as much root mass in this zone in Year 1 and four times as much root mass in this zone in Year 2. No differences in root mass were found among cultivars within either species at 3 to $12 \mathrm{~cm}$ (Table 1). Root mass in the 3- to 12-cm depth was greatest on 20 June, 7 July, and 5 Oct. in Year 1 and exhibited a summer decline from 24 July until 21 Sept. (Fig. 2). Like with total root mass in Year 1, a fall recovery was observed in the 3- to 12-cm depth followed by a decline in the late fall for all cultivars (Fig. 2). In Year 2, the root mass in the 3 - to $12-\mathrm{cm}$ depth was relatively constant throughout the growing season and the pattern of growth was similar to that of total root mass.

'Penn A-4' had greater root mass below $12 \mathrm{~cm}$ compared with 'Penncross'. The difference in root mass below the 12-cm depth was the only consistent difference in root mass between 'Penn A-4' and 'Penncross' at any depth throughout both years of the experiment (Fig. 3). On three occasions in Year 1 , both bentgrass cultivars showed more root mass below $12 \mathrm{~cm}$ in the $65 \mathrm{~kg} \mathrm{~N} / \mathrm{ha} /$ year compared with the $195 \mathrm{~kg} \mathrm{~N} / \mathrm{ha} /$ year treatment. Root mass means across all harvest dates for 'Penn A-4' were $0.025 \mathrm{~g}$ and $0.022 \mathrm{~g}$ for the $65 \mathrm{~kg} \mathrm{~N} / \mathrm{ha} /$ year and $195 \mathrm{~kg} \mathrm{~N} /$ ha/year treatments, respectively, and 0.017 and $0.014 \mathrm{~g}$ for the 'Penncross' $65 \mathrm{~kg} \mathrm{~N} / \mathrm{ha} /$ year and 195 $\mathrm{kg} \mathrm{N} /$ ha/year treatments, respectively. The annual bluegrass selections had very little root mass below $12 \mathrm{~cm}$ of depth, and in the summer months, the root mass in this zone approached zero (data not shown). In Year 1, a pattern of root mass decline and recovery was observed in this section of the root zone that was similar to that observed in the zones above it (Fig. 3). This pattern was not observed in Year 2 because the 'Penn A-4' root mass declined from 18 June to the end of the sampling period, whereas 'Penncross' exhibited no change across the same sampling dates.

Specific root lengths of cultivars and selections within the two species were pooled because no differences were observed. Creeping 


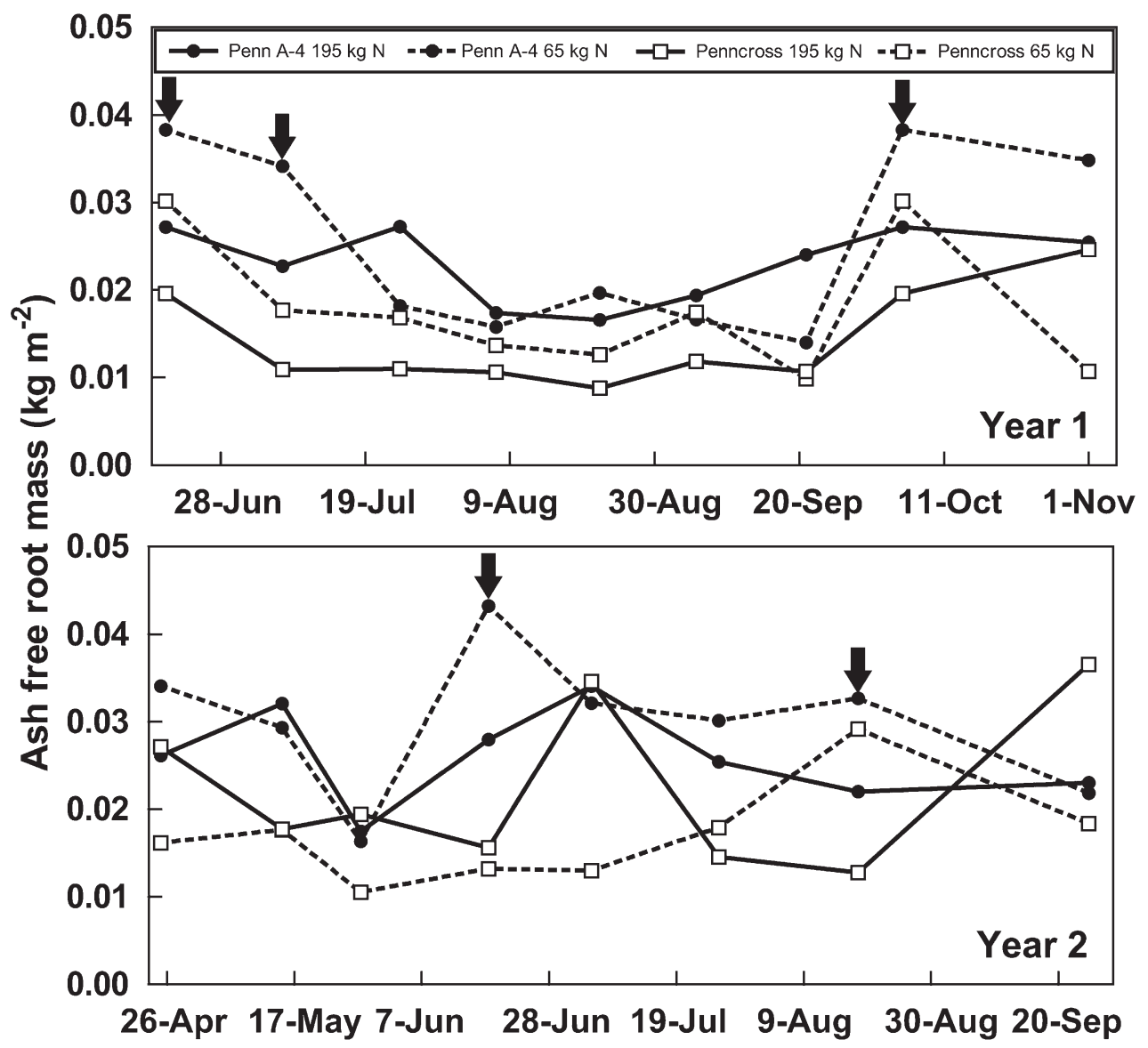

Fig. 3. Root mass (ash free) in the below 12-cm fraction per meter squared of surface area of two cultivars of creeping bentgrass ['Penn A-4' and 'Penncross' at two nitrogen rates (195 and $65 \mathrm{~kg} \mathrm{~N} / \mathrm{ha} /$ year)] over 2 years. Arrows represent dates there was greater root mass in the plots receiving $65 \mathrm{~kg} \mathrm{~N} / \mathrm{ha} / \mathrm{year}$.

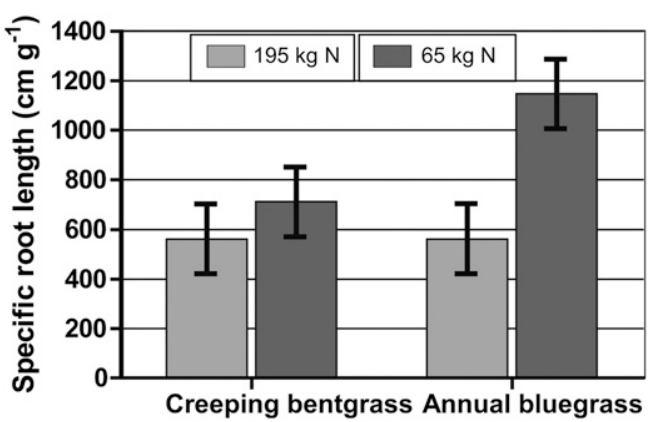

Fig. 4. Average specific root length of two cultivars creeping bentgrass and three experimental cultivars of annual bluegrass at 195 and $65 \mathrm{~kg} \mathrm{~N} / \mathrm{ha} /$ year. The mean represents 15 harvest dates over 2 years.

bentgrass had similar specific root lengths in both the $195 \mathrm{~kg} \mathrm{~N} / \mathrm{ha} /$ year and $65 \mathrm{~kg} \mathrm{~N} / \mathrm{ha} /$ year treatments (Fig. 4). Specific root lengths of creeping bentgrass in the $195 \mathrm{~kg} \mathrm{~N} / \mathrm{ha} /$ year and $65 \mathrm{~kg} \mathrm{~N} / \mathrm{ha} /$ year treatments were not different from the specific root lengths of annual bluegrass in the $195 \mathrm{~kg} \mathrm{~N} / \mathrm{ha} /$ year treatment but were significantly lower than the specific root length of annual bluegrass in the $65 \mathrm{~kg}$ $\mathrm{N} /$ ha/year treatment.

In Year 1 of the experiment, 'PSU-97-3' had greater tiller densities than either 'PSU97-1' or 'PSU-97-2' when averaged over the entire growing season (Table 1). 'Penncross' had $\approx 30 \%$ to $40 \%$ lower tiller densities than the other four cultivars of turfgrass, whereas
'Penn A-4' was intermediate between 'Penncross' and the three selections of annual bluegrass. In Year 2, tiller density of 'Penn A-4' was equivalent to 'PSU-97-1' and 'PSU-97-2', whereas 'PSU-97-3' had the highest tiller density (Table 1). 'Penncross' had the lowest tiller density of all cultivars in Year 2.

An increase in tiller density for 'PSU-973' was observed from the first harvest on 20 June to 7 Aug. and a second increase was observed on the 1 Nov. harvest date in Year 1 (Fig. 5). During the fall of Year 2, 'PSU-973 ' showed a slight reduction in tiller density compared with previous harvests, whereas 'Penn A-4' had an increase in tiller density throughout the season (Fig. 5). In Year 1, the
$195 \mathrm{~kg} \mathrm{~N} /$ ha/year treatment produced higher tiller densities for the creeping bentgrass cultivars $\left(47.7\right.$ tillers $\left./ \mathrm{cm}^{2}\right)$ than the $65 \mathrm{~kg} \mathrm{~N} / \mathrm{ha} /$ year treatment $\left(42.6\right.$ tillers $\left./ \mathrm{cm}^{2}\right)$ (data not shown). In Year 2, there was no overall $\mathrm{N}$ effect on tiller density, although there was an interaction between $\mathrm{N}$ rate and day of harvest as tiller density increased with the $65 \mathrm{~kg} \mathrm{~N} /$ ha/year treatment on the $25 \mathrm{Apr} ., 18 \mathrm{Aug}$., and 25 Sept. harvest dates (data not shown). There was no cultivar by $\mathrm{N}$ rate interaction for annual bluegrass, and all three selections were pooled. The $195 \mathrm{~kg} \mathrm{~N} / \mathrm{ha} /$ year rate had increased tiller densities over the $65 \mathrm{~kg} \mathrm{~N} / \mathrm{ha} /$ year rate throughout the experiment (data not shown).

\section{Discussion}

The purpose of this study was to provide a side-by-side comparison of creeping bentgrass and greens-type annual bluegrass rooting distribution and tiller densities at two $\mathrm{N}$ rates under a putting green mowing height throughout two growing seasons. Tiller density has been implicated in the competitiveness of grasses on golf greens (Harivandi et al., 2008). In the present study, the greens-type annual bluegrass cultivars had the highest tiller densities, whereas the Penncross cultivar of creeping bentgrass had the lowest. In addition to having higher tiller densities, cultivars 


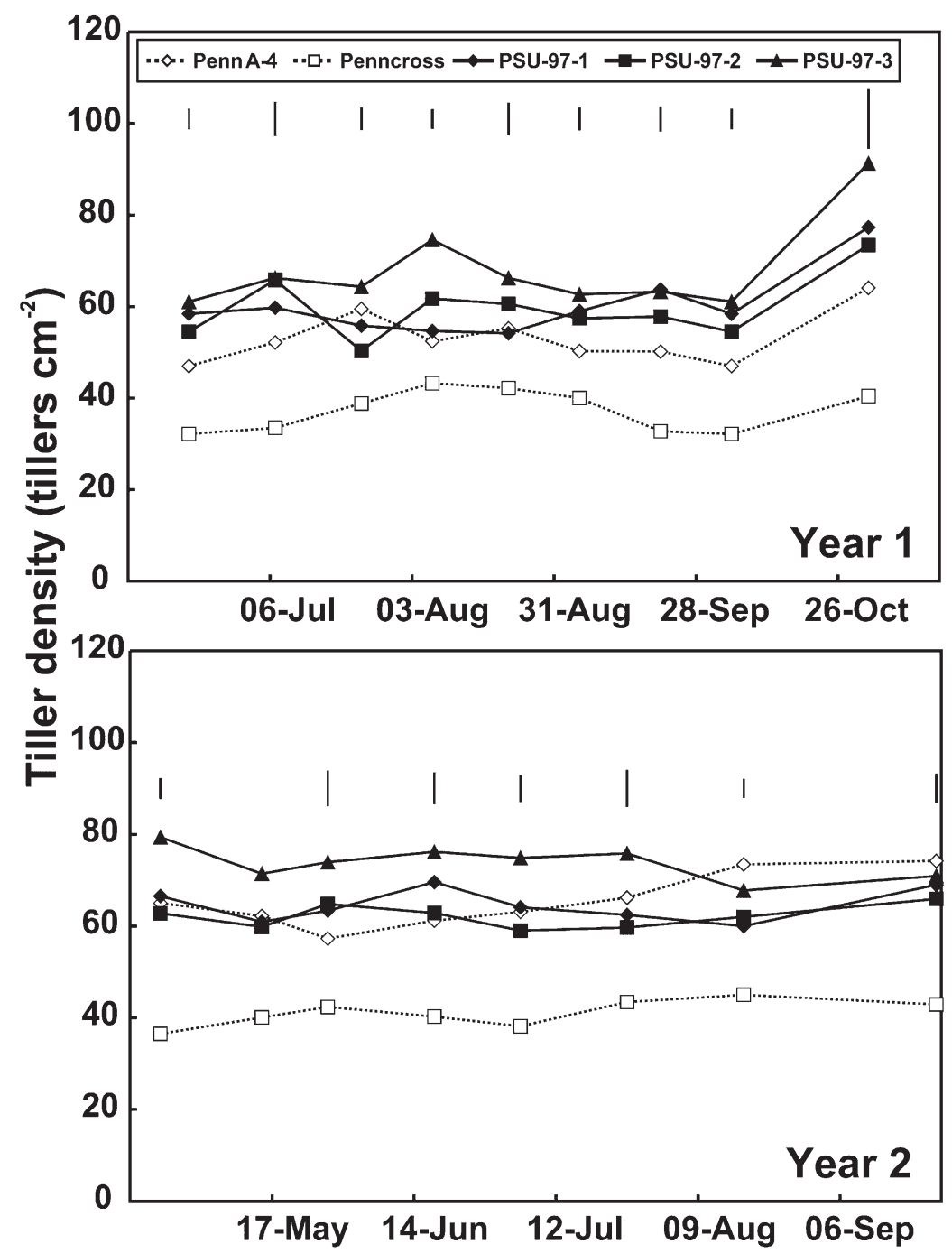

Fig. 5. Tiller density (tillers $/ \mathrm{cm}^{2}$ ) of two cultivars of creeping bentgrass ('Penn A-4' and 'Penncross') and three cultivars of annual bluegrass ('PSU-97-1', 'PSU-97-2', 'PSU-97-3') over 2 years. Bars above each day represent SE values for cultivar differences on each day when day $\times$ cultivar was significant.

of creeping bentgrass entering the commercial market during the 1990s have been reported to develop a more extensive root system (Beard et al., 2001) as was observed with 'Penn A-4' in this study. The high tiller densities observed in some of the new cultivars of bentgrass may be associated with finer leaf texture and stem textures (Beard et al., 2001) and not necessarily the result of a decrease in belowground carbon allocation. The finer-textured bentgrass cultivars may have a lower aboveground carbon demand per tiller than coarser-textured cultivars, thus allowing for similar belowground carbon allocation.

High tiller densities may also allow bentgrass cultivars to expand into disturbed areas such as ball marks or aeration holes through increased vegetative propagation. A grass with higher tiller numbers would have a greater number of potential starting points for stolons and daughter tillers to begin to exploit the disturbed area than a grass with lower tiller densities. Although the $195 \mathrm{~kg} \mathrm{~N} / \mathrm{ha} /$ year rate increased tiller densities of both 'Penncross' and 'Penn A-4' creeping bentgrass in the first
(Schlossberg and Karnok, 2001). Summer root decline adversely affects plants by limiting water and nutrient supply to the shoots (Kramer, 1983). Although all of the cultivars and selections of grasses in our study showed significant summer root decline, 'Penn A-4' was able to maintain the highest total root mass and root mass at deeper soil depths, likely leading to improved stress tolerance during the warmer months of the growing season. This ability may confer a competitive advantage to the 'Penn A-4' on golf greens if water becomes limiting in the late afternoon. If 'Penn A-4' has a greater ability to survive heat stress, and possibly intercept more nutrients throughout the root zone, it would have a competitive advantage over annual bluegrass when water and nutrients are less available or when they are only present deeper in the root zone. The deeper root system of creeping bentgrass, as compared with annual bluegrass, may result in delayed stomatal closure and lead to greater net photosynthesis. Such a response would likely increase summer heat tolerance of creeping bentgrass compared with annual bluegrass.

The root mortality that occurs during summer root decline may be the result of inhibition of carbon supply from shoots to roots at high soil temperatures (Ruter and Ingram, 1990). In creeping bentgrass, Liu and Huang (2002) found that turf plants maintained at a higher cutting height $(4 \mathrm{~mm})$ had a decreased rate of root mortality when compared with plants maintained at lower cutting heights (3 $\mathrm{mm}$ ), indicating the importance of mowing height in maintaining a healthy root system. Closely mowed turfgrasses with limited leaf area may be constrained by their ability to fix a sufficient amount of carbon to support vigorous growth (Huang and Gao, 2000).

The $\mathrm{N}$ in this experiment was applied in liquid form on a regular basis and the plots were watered after fertilizers were applied to maximize root uptake of $\mathrm{N}$. The increase in root mass below $12 \mathrm{~cm}$ at the $65 \mathrm{~kg} \mathrm{~N} / \mathrm{ha} /$ year rate for creeping bentgrass in Year 1 is evidence that this species is maximizing $\mathrm{N}$ uptake by exploring a greater portion of the root zone. Bowman et al. (1998) showed that a cultivar of creeping bentgrass with a deeper, more extensive root system was able to capture more $\mathrm{N}$ than a shallower rooted cultivar. The more extensive creeping bentgrass root mass observed below $12 \mathrm{~cm}$ in the $65 \mathrm{~kg} \mathrm{~N} /$ $\mathrm{ha} /$ year treatments during Year 1 occurred on harvest dates in June and October but not in July and August. The increased resource allocation to root growth at deeper depths in the $65 \mathrm{~kg} \mathrm{~N} / \mathrm{ha} /$ year treatment may only occur when carbon is not limiting. In the summer months, carbon is limiting in closely mowed turfgrass as a result of increased respiration rates and limited photosynthesis (Huang and Gao, 2000; Huang and Liu, 2003). Our results indicate that during the summer period, the plants no longer alter their root growth to increase $\mathrm{N}$ acquisition under the $65 \mathrm{~kg} \mathrm{~N} / \mathrm{ha} /$ year treatment. Another possible explanation is that as the root mass in the deeper portion of the soil declined in summer, the differences 
between the $195 \mathrm{~kg} \mathrm{~N} / \mathrm{ha} /$ year and $65 \mathrm{~kg} \mathrm{~N} / \mathrm{ha} /$ year treatments were too small to be detected.

Annual bluegrass is most competitive during times when temperatures are moderate, like in the spring and fall (Lush, 1988). The limited root system of annual bluegrass may be a primary cause for its lack of competitiveness in the warmer summer months. The ability of plants to spatially and temporally access nutrient supplies is an important factor in determining nutrient uptake and a determining factor in plant competition (Crick and Grime, 1987; Hodge et al., 1999; Jackson and Caldwell, 1996). Plant growth on golf greens is severely limited by low mowing heights (Hull, 1992). It is possible that the limited root system of annual bluegrass is a result of evolution under low mowing heights.

Another explanation for the competitive nature of annual bluegrass on creeping bentgrass golf putting greens is its ability to alter its specific root length in response to nutrient availability. Specific root length often increases in response to low nutrient availability (Fitter, 1985). The increase in specific root length could also have implications in the carbon balance of the plant. Although thicker roots are more costly to produce, they have greater transport capacity (Fitter, 1987), possibly aiding in water acquisition. Because the $\mathrm{N}$ in our study was applied uniformly to the soil surface, the increase in specific root length of the annual bluegrass may have been more apparent because a greater percentage of annual bluegrass root mass exists in the upper soil layers. Plants with higher specific root lengths, or finer roots, tend to have more rapid proliferation of roots than plants with thicker roots such as in tussock grasses (Eissenstat and Caldwell, 1987). High specific root length is associated with roots growing into nutrient rich patches (Huang, 1999; Huante et al., 1998; Lariguaderie and Richards, 1994), and carbon allocation needed per unit of root length is lower for plant roots with a higher specific root length (Eissenstat, 1992; Huang and Eissenstat, 2000). Low mowing heights severely limit the energy available for root growth and have been shown to limit the total root mass in creeping bentgrass (Hull, 1992). The ability of annual bluegrass to increase its specific root length in response to the $65 \mathrm{~kg}$ $\mathrm{N} /$ ha/year rate observed in the present study may allow an increase in total root length without increasing its root mass, thereby increasing nutrient acquisition with less belowground carbon allocation than other grasses. This would allow the annual bluegrass to acquire nutrients more efficiently than creeping bentgrass in a carbon-limited environment.

Findings from the present experiment confirm a long-held belief that annual bluegrass has fewer total roots and fewer roots deeper in the soil than creeping bentgrass when grown under golf green management conditions. Both species experienced a decline in rooting at all depths throughout the summer months as a result of high temperatures, which can be attributed by carbon deficits caused by a reduction in photosynthesis and a corresponding increase in respiration of roots (Huang and
Gao, 2000; Huang and Liu, 2003). Finally, creeping bentgrass responded to low $\mathrm{N}$ in soil by increasing root mass below $12 \mathrm{~cm}$, whereas annual bluegrass had an increase in specific root length, possibly improving competitiveness under carbon-limited environments like a golf green mowed between 2.5 and $4 \mathrm{~mm}$.

\section{Literature Cited}

Beard, J.B. 1973. Turfgrass: Science and culture. Prentice Hall, Englewood Cliffs, NJ.

Beard, J.B., P. Croce, M. Mocioni, A. De Luca, and M. Volterrani. 2001. The Comparative competitive ability of thirteen Agrostis stolonifera cultivars to Poa апnиа. Intl. Turfgrass Soc. Res. J. 9:828-831.

Beard, J.B., P.E. Reike, A.J. Turgeon, and J.M. Vargas, Jr. 1978. Annual bluegrass (Роа аппиа L.): Description, adaptation, culture and control. Res. Rpt Michigan State University Agr. Expt. Sta.

Bell, R.S. and J.A. Defrance. 1944. Influence of fertilizers on the accumulation of roots from closely clipped bentgrasses and on the quality of turf. Soil Sci. 58:17-24.

Bowman, D.C., D.A. Devitt, M.C. Engelke, and T.W. Rufty, Jr. 1998. Root Architecture affects nitrate leaching from bentgrass turf. Crop Sci. 38:1633-1638.

Christians, N.E., D.P. Martin, and J.F. Wilkinson. 1979. Nitrogen, phosphorus and potassium effects on quality and growth of kentucky bluegrass and creeping bentgrass. Agron. J. 71:564-567.

Crick, J.C. and J.P. Grime. 1987. Morphological plasticity and mineral nutrient capture in two herbaceous species of contrasted ecology. New Phytol. 107:403-414.

Dest, W.M. and K. Guillard. 1987. Nitrogen and phosphorus nutritional influence on bentgrassannual bluegrass community composition. J. Amer. Hort. Soc. 112:769-773.

Eissenstat, D. 1992. Costs and benefits of constructing roots of small diameter. J. Plant Nutr. 15:763-782.

Eissenstat, D.M. and M.M. Caldwell. 1987. Characteristics of successful competitors: An evaluation of potential growth rate in two cold desert tussock grasses. Oecologia 71:167173.

Fitter, A.H. 1985. Functional significance of root morphology and root systems architecture, $\mathrm{p}$. 87-106. In: Fitter, A.H., D. Atkins, D.J. Read, and M.B. Usher (eds.). Ecological interactions in soil. Spec. Publ. Brit. Ecol. Soc. No. 4. Blackwell Scientific, Oxford, UK.

Fitter, A.H. 1987. An architectural approach to the comparative ecology of plant root systems. The New Phytologist 106(suppl):61-77.

Staff, G.S. 1993. USGA recommendations for a method of putting green construction. USGA Green Section Rec. 31:1-3.

Harivandi, M.A., W.B. Hagan, and K.N. Morris 2008. Evaluating bentgrass for quality, ballroll distance, thatch/mat development and annual bluegrass invasion. Acta Hort. 783:309316.

Hodge, A., D. Robinson, B.S. Griffiths, and A.H. Fitter. 1999. Why plants bother: Root proliferation results in increased nitrogen capture from an organic patch when two grasses compete. Plant Cell Environ. 22:811-820.

Huang, B. 1999. Water relations and root activities of Buffalo Zoysiagrass in relation to localized soil drying. Plant Soil 208:179-186.

Huang, B. and D.M. Eissenstat. 2000. Root plasticity in exploiting water and nutrient hetero- geneity, p. 111-132. In: Wilkinson, R.E. (ed.). Plant-environment interactions. Marcel Dekker, New York, NY.

Huang, B. and H. Gao. 2000. Growth and carbohydrate metabolism of creeping bentgrass cultivars in response to increasing temperatures. Crop Sci. 40:1115-1120.

Huang, B. and X. Liu. 2003. Summer root decline: Production and mortality for four cultivars of creeping bentgrass. Crop Sci. 43:258-265.

Huante, P., E. Rincon, and F.S. Chapin, III. 1998. Foraging for nutrients, responses to changes in light and competition in tropical deciduous tree seedlings. Oecologia 117:209-216.

Huff, D.R. 2003. Chapter 2: Annual bluegrass, p. 27-38. In: Casler, M. and R. Duncan (eds.). Turfgrass biology, genetics, and breeding. John Wiley and Sons, Hoboken, NJ.

Huff, D.R. 2004. Developing annual bluegrass cultivars for putting greens. USGA Turfgrass and Environmental Research Online 3:1-8. 7 Sept. 2011. <http://usgatero.msu.edu >. Also published in the Green Section Record. United States Golf Association. Sept/Oct. 2004.

Hull, R.J. 1992. Energy relations and carbohydrate partitioning in turfgrasses. In: Waddington, D.V., R.N. Carrow, and R.C. Shearman (eds.). Turfgrass. Agronomy Monograph. Vol. 32. ASA, CSSA, SSSA, Madison, WI.

Jackson, R.B. and M.M. Caldwell. 1996. Integrating resources heterogeneity and plant plasticity: Modeling nitrate and phosphate uptake in a patchy soil environment. J. Ecol. 84: 891-903.

Kohlmeier, G.P. and J.L. Eggens. 1983. The influence of wear and nitrogen on creeping bentgrass growth. Can. J. Plant Sci. 63:189193.

Kramer, P. 1983. Water relations of plants. Academic Press, New York, NY.

Kurtz, K.J. and W.R. Kneebone. 1980. Influence of aeration and genotype upon root growth of creeping bentgrass under supraoptimal temperatures, p. 145-148. In: Roberts, E.C. (ed.). Proc. Third Int. Res. Conf. ASA and CSSA, and the International Turfgrass Society, Madison, WI.

Lariguaderie, A. and J.H. Richards. 1994. Root proliferation characteristics of seven perennial arid-land grasses in nutrient-enriched microsites. Oecologia 99:102-111.

Litell, R.C., G.A. Milliken, W.W. Stoup, and R.D. Wolfinger. 1996. SAS system for mixed models. SAS Institute, Inc., Cary, NC.

Liu, X. and B. Huang. 2002. Mowing effects on roots production, growth, and mortality of creeping bentgrass. Crop Sci. 42:1241-1250.

Lush, W.M. 1988. Biology of Poa annua in a temperate zone golf putting green (Agrostis stolonifera/Poa апnиa) I. The above-ground population. J. Appl. Ecol. 25:977-988.

Madison, J.H. 1962. Turfgrass ecology: Effects of mowing, irrigation, and nitrogen treatments of Agrostis palustrus Huds., 'Seaside' and Agrostis tenuis Sibth., 'Highland' on population yield, rooting, and cover. Agron. J. 54:407-412.

Ralston, D.S. and W.H. Daniel. 1972. Effect of temperature and water table depth on the growth of creeping bentgrass roots. Agron. J. 64:709-713

Ruter, J.M. and D.L. Ingram. 1990. ${ }^{14}$ Carbonlabeled photosynthate portioning in Ilex crenata at supraoptimal root-zone temperatures. J. Amer. Hort. Sci. 115:1008-1013.

Schlossberg, M.J. and K.J. Karnok. 2001. Root and shoot performance of three creeping bentgrass cultivars as affected by nitrogen fertility. J. Plant Nutr. 24:535-548. 
Schmidt, R.E. and R.E. Blazer. 1967. Effect of temperature, light, and nitrogen on growth and metabolism of 'Cohesy' bentgrass (Agrotis Palustris Huds.). Crop Sci. 7:447-451.

Sprague, H.B. and G.W. Burton. 1937. Annual bluegrass (Poa annua L.), and its requirements for growth, p. 1-24. In: New Jersey Agr. Expt Sta. Bul.
Wang, D., P.M. Sweeney, M.S. McBride, and K.T. Danneberger. 1998. Seasonal rooting and carbohydrate patterns of fifteen creeping bentgrass cultivars, p. 134. In: 1998 Annual Meeting Abstracts. ASA, CSSA, and SSSA, Madison, WI.

Wilkinson, J.F. and D.T. Duff. 1972. Rooting of Poa annua L., Poa pratensis L., and Agrostis palustris Huds. at three soil bulk densities. Agron. J. 64:66-68.

Yeltverton, F. 1999. Seasonal rooting and mowing height effects on 'Penncross' bentgrass in the southern United States. TURFAX 7:4.

Youngner, V.B. 1959. Ecological studies on Poa annua in turfgrasses. J. Br. Grassl. Soc. 14: 233-247. 